RocznikPrzektadoznawczy $6 \overrightarrow{\overline{0}}$ Studia nad teorią, praktyką i dydaktyką przekładu $\bigcirc \stackrel{\circ}{\mathrm{O}}$

Urszula Burda, Agnieszka Dickel, Magdalena Olpińska, Polens Wirtschafts- und Rechtssystem, t. 2: Wirtschaftsordnung, Spracharbeitsbuch, Wyd. C.H. Beck, Warszawa 2008, 118 stron (recenzja książki)

Recenzowana książka jest częścią składającej się z 12 pozycji serii podręczników do nauki niemieckiego języka biznesowego. Jednym z celów wspomnianej serii jest przybliżenie najważniejszych aspektów polskiego systemu prawnego i gospodarczego, których dobre rozpoznanie ma ułatwiać zarówno komunikację specjalistyczną w tym zakresie, jak i tłumaczenie tekstów o tematyce gospodarczej, a także w mniejszym wymiarze prawniczej. Poszczególne tomy stanowią obszerne rozwinięcie poszczególnych lekcji (rozdziałów) książki pilotażowej Wirtschaftsdeutsch. Potencjalnymi odbiorcami serii są polscy studenci kierunków ekonomicznych i prawa, pogłębiający znajomość języka niemieckiego, nauczyciele języka niemieckiego oraz osoby, których praca zawodowa wymaga znajomości języka biznesowego i prawniczego (s. V). Autorki wskazują również na odbiorców niemieckojęzycznych prowadzących swoją działalność gospodarczą w Polsce lub ściśle współpracujących z polskim firmami. W tym wypadku można mieć jednak wątpliwości, czy rzeczywiście niemieckojęzyczni ludzie biznesu zechcą sięgnąć po książkę z ćwiczeniami, by lepiej poznać podstawy polskiego życia gospodarczego i prawnego. Ponieważ sam skutecznie wykorzystuję niektóre podręczniki tej serii na ćwiczeniach przekładu tekstów specjalistycznych, wydaje mi się, że również ta grupa odbiorców (studenci germanistyki i lingwistyki stosowanej uczący się tłumaczenia tekstów specjalistycznych) nie powinna być pomijana.

Książka składa się z 8 części (lekcji) o objętości ok. 8-9 stron każda. Podstawą podziału jest kryterium tematyczne, zatem w każdej części poruszany jest inny temat. Do omawianych tematów należą:

- Prawo gospodarcze i system gospodarczy Polski (lekcja 1),

- Wolność prowadzenia działalności gospodarczej (lekcja 2),

- Prawo insolwencyjne (upadłościowe) i naprawcze, rozwiązanie i likwidacja spółki (lekcja 3),

- Spółki osobowe (lekcja 4),

- Spółki kapitałowe (lekcja 5), 
- Wybrane formy prawne związków, zrzeszeń, spółdzielni, funduszy i fundacji (lekcja 6),

- Krajowy Rejestr Sądowy, urzędy skarbowe, Główny Urząd Statystyczny (lekcja 7),

- Postępowanie sądowe w sprawach gospodarczych (lekcja 8).

Każda z wymienionych lekcji składa się z dwóch głównych części - z części tekstowej i ćwiczeniowej. Część tekstowa składa się, w zależności od tematu, z trzech lub czterech tekstów. Wyjątek stanowi lekcja o spółkach kapitałowych, do której weszły dwa teksty. Część ćwiczeniowa ma we wszystkich lekcjach taką samą, trzyczęściową strukturę, którą tworzą ćwiczenia pisemne do zamieszczonych w lekcji tekstów, ćwiczenia tłumaczeniowe oraz ćwiczenia ustne. Ta struktura umożliwia ćwiczenie trzech różnych kompetencji. W części pierwszej chodzi o pasywne używanie słownictwa specjalistycznego z danej dziedziny, w części tłumaczeniowej następuje pierwszy stopień aktywizacji tego słownictwa oraz jego utrwalenie, a w części ustnej pytania stymulują do aktywnego użycia poznanego słownictwa.

Autorki położyły główny nacisk na ćwiczenia pisemne, wprowadzając sześć różnego rodzaju zadań. W pierwszym należy udzielić odpowiedzi na pytania do tekstu, w drugim - znaleźć odpowiedniki niemieckich zwrotów z języka specjalistycznego, $w$ trzecim - przyporządkować hasła do podanych niżej definicji, w czwartym - utworzyć wyrazy z podanych morfemów i wstawić je w miejsca wykropkowane w tekście, w piątym - ustalić prawdziwość lub fałsz podanych zdań, w szóstym zaś - przyporządkować czasowniki do podanych grup wyrazowych oraz połączyć je z polskim odpowiednikiem. Różnorodność ćwiczeń z pewnością przekonuje, a systematyczne ich wykonywanie i powtarzanie ułatwi bierną i czynną naukę występującego w poszczególnych lekcjach słownictwa specjalistycznego. Ćwiczenie tłumaczeniowe i ustne zostały jednak potraktowane po macoszemu. W pierwszym przypadku autorki ograniczyły się do prośby o przetłumaczenie określonych - dość trudnych - zdań na język niemiecki, przy czym zdania, o które autorkom chodzi, występują często w części tekstowej, co zamiast tłumaczenia może skłaniać do odszukania odpowiedniego zdania $\mathrm{w}$ tekście. Trudno zrozumieć, dlaczego tłumaczenie ma być wykonywane wyłącznie na język niemiecki. Rozbudowa tej części przez dodanie i urozmaicenie ćwiczeń byłaby zatem w następnych wydaniach książki wskazana. Ciekawym ćwiczeniem mogłoby być tłumaczenie w obie strony stosunkowo prostych krótkich tekstów, w których słownictwo z danej jednostki tematycznej występowałoby w mniejszym zagęszczeniu.

Powyższa uwaga dotyczy również ćwiczeń ustnych. W niektórych lekcjach $(1,2,5,7,8)$ są one bardzo krótkie i bardzo rzeczowe, ale właśnie ta 
rzeczowość bardzo ogranicza spontaniczne wypowiedzi. Przyznać należy, że w pozostałych lekcjach znajdujemy w ćwiczeniach ustnych pytania inspirujące dyskusję (np. 3, a w szczególności 6). Niemniej ta część ćwiczeń jest we wszystkich lekcjach bardzo krótka, co widać po liczbie pytań (z reguły nie więcej niż dwa). Jeżeli miałoby się na celu rozwój kompetencji czynnego używania słownictwa specjalistycznego przerabianej jednostki, należałoby również tę część ćwiczeń rozbudować i urozmaicić. Książka zawiera także krótki glosariusz niemiecko-polski i polsko-niemiecki z najważniejszymi terminami specjalistycznymi, co jest bez wątpienia jej atutem.

Choć omawianą publikację z czystym sumieniem można polecić, bo praca $\mathrm{z}$ nią umożliwia poznanie słownictwa specjalistycznego z zakresu gospodarki, a wybór tematów daje dobry wgląd w rzeczywistość gospodarczą Polski, to jednak autorkom nie udało się uniknąć kilku różnego rodzaju błędów, które powinny być poprawione w kolejnych wydaniach.

W poleceniu trzecim części ćwiczeniowej (w większości lekcji) występuje nieprawidłowa liczba mnoga w słowie Begriff, które występuje w czwartym przypadku - zamiast Begriffe jest Begriffen. Błędem dużo poważniejszym, bo wprowadzającym zamęt, jest brak konsekwencji w tłumaczeniu nazwy własnej Krajowy Rejestr Sądowy. W glosariuszu i w zdecydowanej większości miejsc występuje jako Landesgerichtsregister, co jest zgodne z obecną praktyką tłumaczeniową w Polsce. Jednak na stronie $30 \mathrm{w}$ ćwiczeniu 6 znajdujemy obok polskiej frazy złożyć wniosek o wykreślenie z Krajowego Rejestru Sądowego niemiecki odpowiednik w formie den Antrag auf Löschung im Landesjustitzregister stellen. Choć słowa różnią się tylko środkową częścią złożenia (-gerichts- => -justitz-), to biorąc pod uwagę powszechnie uznawaną zasadę stosowania tych samych odpowiedników do określonych słów czy pojęć w tłumaczeniu tekstów specjalistycznych, taki błąd nie powinien się zdarzyć.

Błędem podobnego typu jest używanie dwóch różnych ekwiwalentów do terminu akt założycielski (spółki). W glosariuszu w obu wersjach językowych występuje w charakterze ekwiwalentu kalka polskiego terminu Gründungsakt, w tekście zaś pojawia się obok niego bliższy mi termin Gesellschaftsvertag (umowa spótki), który nie znalazł się $\mathrm{w}$ ogóle $\mathrm{w}$ glosariuszu. Ten termin w dookreślonej formie (notariell beurkundeter Gesellschaftsvetrag) występuje w praktyce tłumaczeniowej w Polsce jako odpowiednik aktu założycielskiego spótki. W podobnym duchu czytamy na stronie 44: „Zur Entstehung einer $\mathrm{GmbH}$ ist Abschluss eines Gesellschaftsvertrages [...] in Form einer notariellen Urkunde nötig". W innym miejscu na tej samej stronie termin ten został powtórzony. Na podstawie porównania systemów prawnych, w tym przypadku niemieckiej ustawy o spółkach z o.o. oraz odpowiednich fragmentów 
polskiego kodeksu spółek handlowych, można stwierdzić, że w obu przypadkach występuje termin umowa spółki (Gesellschaftsvertrag). Termin akt zało$\dot{z} y c i e l s k i$ pojawia się ponadto $\mathrm{w}$ wymienionym wyżej kodeksie tylko w jednym miejscu (art $4 \$ 2$ ), w którym znajdujemy wyraźne wskazanie na synonimiczną relację obu terminów, przy czym umowa spółki ma znaczenie szersze (ilekroć w ustawie mowa jest o umowie spółki, należy przez to rozumieć także akt założycielski sporządzony przez jednego wspólnika albo akcjonariusza spółki kapitałowej). Przyjmując teorię tłumaczenia terminów prawnych i prawniczych de Groota (2002), kalka językowa wydaje się zbędna, tym bardziej że w miejscu, w którym jest mowa o tym, co musi zawierać umowa spółki, zarówno w ustawie polskiej, jak i niemieckiej występuje umowa spółki (Gesellschaftsvertrag), a nie akt założycielski (art $157 \$ 1$ - Umowa spółki z ograniczoną odpowiedzialnością powinna określać; $\$ 3$ niemieckiej ustawy o spółkach z ograniczoną odpowiedzialnością - Der Gesellschaftsvertrag muss enthalten $-\S 3)$.

Innym niedopatrzeniem jest pomylenie rejestrów w lekcji dotyczącej działalności gospodarczej. Cały fragment odnosi się do zwykłej działalności gospodarczej (Einzelunternehmen) i do konieczności zarejestrowania działalności gospodarczej we właściwym urzędzie gminy. W dalszej części (s. 16) mowa jest o tym, że każdy przedsiębiorca musi uzyskać numer REGON w terminie 14 dni od zgłoszenia do Krajowego Rejestru Sądowego (tłum. - L.Z.). Zarówno kolejny fragment, jak i cała strona wskazują na to, że w tym miejscu pomylono dwa terminy - najprawdopodobniej chodzi o Gewerberegister, a nie o Landesgerichtsregister.

Ostatnią kwestią jest użycie terminu z obecnych realiów prawnych w odniesieniu do realiów już nieobowiązujących. Dotyczy to prawa upadłościowego i naprawczego, które weszło w życie w Polsce w 2003 roku, w Niemczech zaś cztery lata wcześniej. Wspomniane prawo zmienia podejście do przedsiębiorstw zagrożonych upadłością, gdyż nie koncentruje się wyłącznie na zaspokojeniu roszczeń wierzycieli. Autorki, opisując sytuację wcześniejszą, powinny zatem stosować adekwatne terminy. Zgodnie z wcześniejszym prawem upadłościowym (w Niemczech: Konkursordnung) w terminologii występowały w języku niemieckim złożenia ze słowem Konkurs-, a nie Insolvenz-. Autorki zauważyły to zresztą, bo tylko w przypadku terminu Insolvenzverwalter (syndyk) nie zachowały konsekwencji (s. 23).

Podsumowując, należy stwierdzić, że wspomniana seria wydawnicza, której jeden element omówiono, zasługuje na uwagę i słowa uznania. Drobne błędy w takim projekcie są trudne do uniknięcia, bo opisywana materia do łatwych nie należy. Wykorzystanie książki na zajęciach przekładoznaw- 
czych jest możliwe w pierwszym etapie pracy, mianowicie przy wprowadzaniu słownictwa specjalistycznego, na którym wspomniana seria wydawnicza skupia swoją główną uwagę.

\section{Literatura i źródła}

Groot de, G.-R., 2002, „Rechtsvergleichnung als Kerntätigkeit bei der Übersetzung juristischer Terminologie", [w:] Sprache und Recht, U. Haß-Zumkehr (red.), Berlin-New York, s. 222-239.

Fijałkowski, T., 2001, Kodeks spółek handlowych oraz prawo działalności gospodarczej, Warszawa.

http://www.gmbh-gesetz.de/ (dostęp: 1 kwietnia 2011 r.)

Lech Zieliński

(Toruń) 
(cc) (i) $\fallingdotseq$ 